INTERNATIONAL JOURNAL OF RESEARCHES IN BIOSCIENCES, AGRICULTURE AND TECHNOLOGY (C) VISHWASHANTI MULTIPURPOSE SOCIETY (Global Peace Multipurpose Society) R. No. MH-659/13(N) www.vmsindia.org

\title{
STUDY OF PHYSICO-CHEMICAL CHARACTERISTICS OF SARANGPURI LAKE, DIST-WARDHA (M.S.)
}

\author{
U. W. Fule ${ }^{1}$, S. S.Nimgare ${ }^{1}$ and P.M.Telkhade ${ }^{2}$ \\ ${ }^{1}$ Hutatma Rashtriya Arts and Science College, Ashti. \\ ${ }^{2}$ Arts, Commerce and Science College, Tukum, Chandrapur \\ patankar.kargi@gmail.com
}

\begin{abstract}
:
People on globe are under tremendous threat due to undesired changes in the physical, chemical and biological characteristics of air, water and soil. Due to increased human population, industrialization, use of fertilizers and man-made activity water is highly polluted with different harmful contaminants. Physico-chemical characteristics study of Sarangpuri lake District-Wardha was carried out from year 2008-09. The water is used for irrigation of the field. The parameters studied includes ambient Temperature, water Temperature, $\mathrm{pH}$, Conductivity, Transparency, Dissolved Oxygen, Free $\mathrm{CO}_{2}$, Total Alkalinity, Calcium Hardness, Magnesium Hardness, TDS, TS,BOD, COD. The monthly analysis over the period of one year suggest that the lake water is suitable for drinking and Domestics purposes.
\end{abstract}

Keyword: Water, Physico - Chemical, Parameters, Hardness, BOD.

\section{Introduction:}

Water is one of the most important and abundant compounds of the ecosystem. All living organisms on the earth need water for their survival and growth. As of now only earth is the planet having about $70 \%$ of water. But due to increased human population, industrialization, use of fertilizers in the agriculture and man-made activity it is highly polluted with different harmful contaminants. Natural water contaminates due to weathering of rocks and leaching of soils, mining processing etc. It is necessary that the quality of drinking water should be checked at regular time interval, because due to use of contaminated drinking water, human population suffers from varied of water borne diseases. The availability of good quality water is an indispensable feature for preventing diseases and improving quality of life. It is necessary to know details about different physico-chemical parameters such as temperature, Transparency, Hardness, pH, $\mathrm{DO}, \mathrm{CO}_{2}$, TDS,TS,BOD, COD, alkalinity used for testing of water quality.

Adequate level of dissolved oxygen is essential for the self purification process in natural water systems. The DO level may indicate the effect of oxidisable wastes on receiving waters. It also indicates the capacity of a natural body of water for maintaining aquatic life and may be derived from the atmosphere and photosynthetic activity of the aquatic plants. Carbon di-oxide is added to aquatic ecosystem by directly being mixed from atmosphere, In addition to this, the other sources are rain water, inflowing ground water and the respiration of aquatic flora and fauna. Biochemical oxygen Demand (BOD) is the amount of oxygen utilized by micro organism is stabilizing the organic matter in aerobic condition DO measurement forms the basis of BOD analysis. It gives an indication of load of biodegradable organic materials present in the water body.

Organic matter in a sample also can be reacted directly with oxygen at a high temperature to produce carbon dioxide. Too much organic matter addition to the lentic and Iotic system increases the levels of COD and changes the composition of oxygen requiring organisms variation in the organic matter in turn, changes in COD levels show diversity in the autotrophic and heterotrophic populations and decreases the productivity status. The energy budgets of the aquatic bodies also directly related to the levels of chemical oxidation in prescribed periods. (Dakshin and Soni, 1979). The present study deals with physico-chemical parameters of Sarangpuri reservoir during 2008-09.

\section{Material and Methods:} Physical Parameters-

1) For measurement of Temperature, $\mathrm{pH}$ and Conductivity of water of Sarangpuri reservoir, portable digital water analysis kit was used and Transparency of water was measured by Secchi disc.

\section{Chemical Parameters-}

1) Dissolved Oxygen: Dissolved oxygen from water samples was determined by Wrinkler's iodide azide method.

2) Free Carbon Dioxide: Free carbon dioxide from water samples was determined by titrimetric method.

3) Alkalinity: Alkalinity of water was estimated by titrimetric method.

4) Total Hardness: Total hardness of water 
samples was estimated by titrimetric method.

5) Calcium Hardness: Calcium hardness of water samples was estimated by titrimetric method.

6) Magnesium Hardness: Magnesium hardness of water samples was estimated by titrimetric method.

7) Total Solids, Total Dissolved Solids: Total Solids, Total Dissolved Solids and Total Suspended Solids were estimated by Gravimetric method.

8) Chemical Oxygen Demand (COD): For determination of chemical oxygen demand, titrimetric method was used.

\section{Result and Discussion: \\ Physico-chemical parameters-}

Monthly variation and annual average of the physico-chemical parameters analysed are represented in Table- 1.1

\section{Ambient Temperature-}

In the present investigation, the ambient temperature ranged between $27.05^{\circ} \mathrm{C}$ to $43.50^{\circ} \mathrm{C}$ during the year 2008-09. The minimum ambient temperature was recorded in the month of January and maximum in May. Similar results were also observed by Lendhe and Yeragi (2004). Similarly Ganesan and Sultana (2009) stated that atmospheric Temperature ranged between $30{ }^{\circ} \mathrm{C}$ to $39{ }^{\circ} \mathrm{C}$ in Chropetlake. Aher et al., (2007) observed Atmospheric temperature was higher in summer while lower in winter at Kagdipura swamp.

\section{Water Temperature-}

In the present investigation, the water temperature ranged between $22.00^{\circ} \mathrm{C}$ to $36.50^{\circ} \mathrm{C}$ during the year 2008-09. The minimum water temperature was recorded in the month of January and maximum in the month of May. Thakare et al., (2002) recorded water temperature between $32.0^{\circ} \mathrm{C}$ to $37.0{ }^{\circ} \mathrm{C}$ in Dhamaswadi lake, Latur. Dhere and Gaikwad (2006) recorded the range of water temperature between $25.20{ }^{\circ} \mathrm{C}$ to $34.0^{\circ} \mathrm{C}$ in Karpara reservoir, Parabhani (M.S.)

pH-

In the present investigation, the $\mathrm{pH}$ ranged between 7.09 to 8.10 during the year 2008-09. The minimum $\mathrm{pH}$ was recorded in the month of January and maximum in the month of June during the year 2008-2009. Kulshrestha et al., (1992) studied the Mansarovar reservoir and recorded the $\mathrm{pH}$ in range of 7.2 to 9.5 . Kulkarni and Zade (2012) stated that the water was alkaline throughout the year with no definite seasonal variation.

\section{Conductivity-}

In the present investigation, the conductivity ranged between $0.198 \mu$ mhos $/ \mathrm{cm}$ to $0.430 \mu$ mhos/cm during the year 2008-09. The minimum conductivity was recorded in the month of February and maximum in the month of July. These values are quite similar with Narayana et al., (2008). Dutta and Bhagawati (2007) recorded the conductivity range between 12.00 to $15.5 \mu$ mhos $\mathrm{cm}-1$ in December and 97.00 to 98.5 umhos $\mathrm{cm}-1$ in April from Ox-bow lake of Assam. Khabade et al., (2002) observed the range of conductivity between 0.420 $\mu \mathrm{mhos} / \mathrm{cm}$ to $0.604 \mu \mathrm{mhos} / \mathrm{cm}$ in Lodhe water reservoir from Tasg

\section{Transparency-}

In the present investigation, the transparency ranged between $25.00 \mathrm{~cm}$ to 60.00 $\mathrm{cm}$ during the year 2008-09. The minimum transparency was recorded in the month of June and maximum in the month of February. Similarly, Bobdey and Sawane (2012) stated that transparency is inversely proportional to the turbidity created by inorganic and organic matter, the range of transparency range between $110 \mathrm{~cm}$ to $80 \mathrm{~cm}$ in Gandhisagar lake. Pulle (2000) observed the transparency values in the range of $28.4 \mathrm{~cm}$ to $87.8 \mathrm{~cm}$ in Isapur dam and further reported that the transparency was maximum in month of May and minimum in August. Kadam et al., (2007) recorded the range of transparency between 41.5 to $95.0 \mathrm{~cm}$ and 35.0 to $10.5 \mathrm{~cm}$ at two stations respectively, from Masoli reservoir, District Parabhani, Maharashtra.

\section{Dissolved Oxygen (DO)-}

In the present investigation, the dissolved oxygen ranged between $3.90 \mathrm{mg} / \mathrm{ltr}$ to 10.87 $\mathrm{mg} /$ ltr during the year 2008-09. The minimum Dissolved Oxygen was recorded in the month of May and maximum in the month of January. Jadhav et al., (2012) stated that amount of DO in water is important source of oxygen for respiration of aquatic organisms and observed values of DO range from 5.2 to $8.2 \mathrm{mg} / 1 \mathrm{tr}$ at Bori reservoir. Thakor et al., (2011) observed average DO $5.9 \mathrm{mg} / \mathrm{L}$ during rainy season 5.4 $\mathrm{mg} / \mathrm{ltr}$ during winter and $4.9 \mathrm{mg} / \mathrm{ltr}$ during summer season. Paka and Rao (1997) recorded the range of DO between 2.8 to $13.6 \mathrm{mg} / 1 \mathrm{tr}$ from Osmania University pond, Hyderabad

\section{Free Carbon dioxide (Free $\mathrm{CO}_{2}$ )-}

In the present investigation, the Free $\mathrm{CO}_{2}$ ranged between $2.56 \mathrm{mg} / \mathrm{ltr}$ to $4.44 \mathrm{mg} / \mathrm{ltr}$ during the year 2008-09. The minimum Free $\mathrm{CO}_{2}$ was recorded in the month of January and 
maximum in the month of April. Similarly, Rama Devi (2007) recorded the range between $1.7 \mathrm{mg} / \mathrm{ltr}$ to $2.8 \mathrm{mg} / \mathrm{ltr}$ from Ali Sagar dam. Chouhan and Sharma (2007) reported a minimum $\mathrm{CO}_{2}, 4.40 \mathrm{mg} / \mathrm{ltr}$ in month of June and maximum $44.0 \mathrm{mg} / \mathrm{ltr}$ in month of August from a religious lake Budha Pushkar near Ajmer, Rajasthan.

\section{Total Alkalinity-}

In the present investigation, the total alkalinity ranged between $178.00 \mathrm{mg} / \mathrm{ltr}$ to $365.00 \mathrm{mg} / \mathrm{ltr}$ during the year 2008-09. The minimum total alkalinity was recorded in the month of March and maximum in the month of October. Similarly, Warhate and Chauhan (2012) observed range of alkalinity values $230.8 \mathrm{mg} / \mathrm{L}$ to $370 \mathrm{mg} / \mathrm{ltr}$ in an around MIDC area Chikhalathant near Naregaon. Kumar et al., (2007) studied urban pond Telibandha, Raipur and reported alkalinity between $64.5 \mathrm{mg} / \mathrm{ltr}$ to $317 \mathrm{mg} / \mathrm{ltr}$.

\section{Total Hardness-}

In the present investigation, the total hardness ranged between $73.00 \mathrm{mg} / \mathrm{ltr}$ to $157.00 \mathrm{mg} / \mathrm{ltr}$ during the year 2008-09. The minimum total hardness was recorded in the month of February and maximum in the month of May. Similarly, Thomas et al., (2011) observed the range of total hardness $230 \mathrm{mg} / \mathrm{L}$ to $457 \mathrm{mg} / \mathrm{L}$ with no significant variation. Kulkarniet.al, (1995) reported the range of hardness between $76.3 \mathrm{ppm}$ to $172 \mathrm{ppm}$ in Sadatpur reservoir at Ahemadnagar

\section{Calcium Hardness-}

In the present investigation, the Calcium hardness ranged between $51.00 \mathrm{mg} / \mathrm{ltr}$ to 97.00 $\mathrm{mg} / \mathrm{ltr}$ during the year 2008-09. The minimum Ca- hardness was recorded in the month of February and maximum in the month of July. Solanki (2006) reported Calcium content fluctuation between $21.66 \mathrm{pp}$ to $66.44 \mathrm{ppm}$, average $39.86 \mathrm{ppm}$ in Bellallake, Bodhan. Khobragade (2003) reported the calcium and magnesium hardness values in range of 56.11 to $160 \mathrm{mg} / \mathrm{ltr}$ and $36 \mathrm{mg} / \mathrm{ltr}$ to $104.2 \mathrm{~m}$

\section{Magnesium Hardness-}

In the present investigation, the Magnesium hardness ranged between $22.00 \mathrm{mg} / 1 \mathrm{tr}$ to 68.00 $\mathrm{mg} / \mathrm{ltr}$ during the year 2008-09. The minimum $\mathrm{Mg}$ - hardness was recorded in the month of February and maximum in the month of May. Solanki (2006) reported the Mg-hardness content varied between 32.74 to $99.46 \mathrm{ppm}$ in Bellallake.

\section{Total Solids (TS) and Total Dissolved Solids (TDS)-}

In the present investigation, the TS ranged between $540.00 \mathrm{mg} /$ ltr to $925.00 \mathrm{mg} / \mathrm{ltr}$ during the year 2008-09. The minimum total solid was recorded in the month of February and maximum in the month of September. Trivedi et al., (2007) reported that total solid between 85 to $410 \mathrm{mg} / \mathrm{ltr}$ at closed Beel of Kalyani industrial area of West Bengal. Khanna and Bhutiani (2003) recorded the average value of total solids as $558.89 \mathrm{mg} / \mathrm{ltr}$ from Sitapur pond at Haridwar. In the present investigation the TDS ranged between $403.00 \mathrm{mg} / \mathrm{ltr}$ to 602.00 $\mathrm{mg} /$ ltr during the year 2008-09. The minimum total dissolved solids was recorded in the month of January and maximum in the month of September. Marganwar et al., (2012) observed TDS of Ambazari lake ranges from 252-260 $\mathrm{mg} / \mathrm{ltr}$ with an average $258.6 \mathrm{mg} / \mathrm{ltr}$ and Futala lake $322-357 \mathrm{mg} / \mathrm{ltr}$ with an average 336.3 $\mathrm{mg} / \mathrm{ltr}$.

\section{Biochemical Oxygen Demand-}

In the present investigation the $\mathrm{BOD}$ ranged between $4.46 \mathrm{mg} / \mathrm{ltr}$ to $12.98 \mathrm{mg} / \mathrm{ltr}$ during the year 2008-09. The minimum BOD was recorded in the month of November and maximum in the month of May during year 2013-2014. Kumar et al., (2007) recorded B.O.D. values from 55.92 to $61.22 \mathrm{mg} / \mathrm{ltr}$ in Telibandha pond, Raipur. Anita et al., (2002) recorded the range of B.O.D. from 0.4 to $26 \mathrm{mg} / \mathrm{ltr}$ in Mir Alam Lake, Hyderabad.

\section{Chemical Oxygen Demand-}

In the present investigation the $\mathrm{COD}$ ranged between $16.20 \mathrm{mg} / \mathrm{ltr}$ to $37.50 \mathrm{mg} / \mathrm{ltr}$ during the year 2008-09. The minimum COD was recorded in the month of September and maximum in the month of January. Similarly, Ingole et al., (2009) observed values of COD between 1.9 to $8.15 \mathrm{mg} / \mathrm{L}$ and stated that COD is a measure of oxygen equivalent to the requirement of oxidizing matter content by strong organic oxidizing agent. Mohan et al., (2007) worked on Naya Talab, Jodhpur and recorded the values of C.O.D. between 535.00 $\mathrm{mg} / 1 \mathrm{ltr}$ to $88.00 \mathrm{mg} / \mathrm{ltr}$

In present investigation Sarangpuri lake water was in permissible limit during the monthly analysis over the period of one year and suggests that the lake water is suitable for drinking and Domestics purposes.

Water of good quality is required for living organisms. The quality of water is described by its physical, chemical and microbial characteristics. But, ifsome correlations were possible among these parameters, then significant ones would be fairly useful to indicate the resources as usually described according to its physical, chemical and 
biological or bacteriological characteristics. Therefore it is necessary that the quality of water should be checked at regular time interval, because due to use of contaminated drinking water, human population suffers from varied of water borne diseases. It is difficult to understand the biological phenomenon fully because the chemistry of water revels much about the metabolism of the ecosystem and explain the general hydro - biological relationship (Basavaraja Simpi et al. 2011).

Table 1.1 : Monthly Values of Physico-chemical Parameters of Sarangpuri lake During Year 20082009

\begin{tabular}{|l|l|l|l|l|l|l|l|l|l|l|l|l|l|l|l|}
\hline Sr. No. & Parameters & Jun & Jul & Aug & Sep & Oct & Nov & Dec & Jan & Feb & Mar & Apr & May & Min & Maxi \\
\hline 1 & Ambient Temprature & 40.30 & 38.62 & 37.50 & 34.20 & 34.90 & 33.20 & 30.10 & 27.60 & 37.10 & 38.90 & 41.90 & 44.80 & 27.60 & 44.80 \\
\hline 2 & Water Temprature & 33.10 & 30.20 & 32.10 & 27.30 & 27.60 & 27.50 & 25.40 & 23.40 & 25.60 & 30.90 & 33.10 & 36.50 & 23.40 & 36.50 \\
\hline 3 & pH & 8.10 & 8.05 & 8.12 & 7.85 & 7.75 & 7.60 & 7.12 & 7.23 & 7.28 & 7.46 & 7.98 & 8.05 & 7.12 & 8.12 \\
\hline 4 & Conductivity & 0.365 & 0.398 & 0.420 & 0.356 & 0.289 & 0.310 & 0.301 & 0.289 & 0.198 & 0.254 & 0.260 & 0.289 & 0.198 & 0.420 \\
\hline 5 & Transparency & 28.50 & 29.00 & 29.50 & 31.50 & 34.50 & 39.00 & 40.00 & 55.50 & 59.50 & 45.00 & 53.20 & 46.50 & 28.50 & 59.50 \\
\hline 6 & D.O. & 5.10 & 5.50 & 5.80 & 6.40 & 6.80 & 7.90 & 9.80 & 10.60 & 8.50 & 7.45 & 6.54 & 4.50 & 4.50 & 10.60 \\
\hline 7 & Free CO 2 & 4.12 & 3.50 & 3.12 & 4.12 & 3.65 & 2.90 & 2.86 & 2.45 & 3.20 & 4.23 & 3.52 & 4.12 & 2.45 & 4.23 \\
\hline 8 & Total Alkalinity & 296 & 310 & 345 & 365 & 345 & 295 & 250 & 235 & 235 & 186 & 245 & 356 & 186.00 & 365.00 \\
\hline 9 & Total Hardness & 122 & 126 & 145 & 156 & 125 & 121 & 98 & 86 & 75 & 98 & 125 & 154 & 75.00 & 156.00 \\
\hline 10 & Ca-Hardness & 86 & 97 & 101 & 106 & 97 & 85 & 74 & 63 & 59 & 63 & 78 & 84 & 59.00 & 106.00 \\
\hline 11 & Mg-Hardness & 36 & 29 & 44 & 50 & 28 & 36 & 24 & 23 & 16 & 35 & 47 & 70 & 16.00 & 70.00 \\
\hline 12 & TS & 760 & 856 & 895 & 936 & 856 & 745 & 689 & 545 & 530 & 645 & 689 & 679 & 530.00 & 936.00 \\
\hline 13 & TDS & 534 & 569 & 610 & 645 & 580 & 526 & 465 & 403 & 421 & 468 & 508 & 487 & 403.00 & 645.00 \\
\hline 14 & BOD & 8.12 & 7.30 & 6.50 & 6.02 & 5.20 & 4.89 & 4.65 & 5.98 & 8.94 & 9.45 & 11.23 & 12.50 & 4.65 & 12.50 \\
\hline 15 & COD & 19.50 & 18.20 & 16.50 & 15.30 & 21.50 & 27.60 & 32.40 & 34.51 & 32.50 & 31.20 & 34.60 & 35.90 & 15.30 & 35.90 \\
\hline
\end{tabular}

\section{References:}

Aher, S.K., Mane U.H. and Pawar B.A. (2007): A study on physico- chemical parameters of Kagdipura Swamp in relation to pisciculture, near Aurangabad, (M.S). India J.Aquaboil., Vol. 22 (1) Pp. 93-96

Anitha, G. (2002): Hydrography in relation to benthic macro-invertebrates in Mir-Alam lake Hyderabad, Andhra Pradesh, India. Ph.D. Thesis submitted to Osmnaia University, Hyderabad. A. P. India..

Basavaraja, Simpi, S. M., Hiremath, K. N. S. Murthy, K. N. Chandrashekarappa, Anil N. Patel, E.T.Puttiah, (2011), Analysis of Water Quality Using Physico-Chemical Parameters Hosahalli Tank in Shimoga District, Karnataka, India, Global Journal of Science Frontier, Research, 1(3), pp 31-34.

Chouhan, C.S. and Sharma K.C. (2007): Limno-biotic of a religious Lake Budha Pushkar near Ajmer, Rajasthan. NSL: Pp.227 - 230.

Dutta, O.K and Bhagabati S. K. (2007): Limnology of Ox-bow Lake of Assam. NSL: Pp 3 - 7 .

Ganesan, S. and Mazher Sultana (2009): A base line study of physico- chemical parameters and some trace metals in water Chrompet lake, Channai, India. $J$. Aqua. Biol. Vol.24 (2) Pp. 131-141

Ingole, S.B., Pawale R.G. and Wavde P.N. (2009): water quality studies on Majalgaon Dam, District Beed M.S. J.Aquaboil., Vol. 24(1) Pp. 71-76

Jadhav, H.K., Babare A.D. and Babare M.G. (2012): Physico- chemical characteristics of Bori reservoir at Naldurg, District Osmanabad. J. of Sciinfor. Spe.Issu Pp.124-125

Kadam, M.S., Pampatwar D.V. and Mali R.P. (2007): Seasonal variations in different physico-chemical characteristics in Masoli reservoir of Parbhani District. Maharashtra.J.Aqua. Biol., Vol. 22 (2): Pp.110 - 112.

Khabade, S.A., Mule M.B. and Sathe S.S. (2002): Studies on Physico-chemical parameters of Lodhe water reservoir from Tasgaontahsil. Maharashtra Indian J.Environ \& Ecoloplan 6(2): Pp.301-304.

Kukarni, R. and Zade S.B. (2012): Assessment of some physico -chemical characteristic of recreational water body, Ramalalake in Chandrapur India, with special reference to eutrophication. BionanoFronters, Spe.Issu. Pp. 63-66.

Kulkarni, S. D. (1995): Diurnal changes in physicochemical characteristics of Sadatpur reservoir J. Aqua. Biol. 10 (1): Pp. 21 - 23.

Kulshrestha, S.K., George M.P., Saxena Rashmi, Johri Malini and Shrivastava Manish (1992): Seasonal variations in the limnological characteristic of Mansarovar reservoir of Bhopal.

Kumar, N., Vardia H.K. and Saxena R.R. (2007): Seasonal variation in physico-chemical characteristics of Urban Pond, Telibandha, Raipur. NSL: Pp.189 - 192. Lendhe, R. S. and Yeragi, S. G.(2004): Physicochemical parameters and zooplankton diversity of PhirangeKharbav

Di.Thane(M.S.),J.Aqua.Biol.,Vol.19(1),pp-49-52.

Marganwar, R., Durvey V., Kodate J. and Dhawas S. (2012): Physico- chemical charectristricts and quality of lake water of Nagpur city, M.S. India .J. Bionano Frontiers Spe.Issu vol. 5 (2-1),Pp. 159-164.

Mohan, Devendra, Gaur Archana and Choudhary Devendra (2007): Study of limnology and microbiology of NayaTalab, Jodhpur (Rajasthan). NSL: Pp.64 - 68.

Narayana, J., Puttaiah E.T., and Basavaraja D. (2008): Water quality characteristic of Anjanpura reservoir near Shikaripura, Shimoga, Karnataka. J.Aqua. Biol. 23 (1), Pp.59-63

Paka, S. and Rao A.N. (1997): Interrelationship of physico-chemical factors of a pond. J. Env. Bio. (18): Pp. $67-72$.

Pulle, J.S. (2000): Biomonitoring of Isapur Dam water. Ph.D. Thesis, Swami Ramanand Teerth Marathwada University, Nanded.

Rama, Devi, T. (2007): Study of some aspects of Hydrobiology of Alisagar Dam water, Ph.D. Thesis submitted, Swami RamanandTeerth, Marathwada University, Nanded.

Solanki, V.R. (2006): Ecological studies on Bellal and Pandu Lakes of Bodhan, A.P. India. Ph.D. Thesis submitted, Osmania University, Hyderabad.

Thomas, D.R. Sunil B. and Latha C. (2011): Physico

Thakre, B.G., Papatwer N.G. and Gaikwad V.B. 
(2002): Studies on Physico-chemical and biological parameters relation to blue revolution with reference to Thaswadi Lake, Latur District.

Thakor, F.J., Bhoi D.K., Dabhi H.R., Pandya S.N. and Chauhan N.B. (2011): Water quality index of Pariyellake District Kheda Gujarat. J. Cur. Wol.Env, Vol 6(2): Pp. 225-231- chemical analysis of well water at Eloor industrial area Seasonal study. J. Cur. Wol. Env, Vol 6(2): Pp. 259 Trivedi, R.K., Suman K. Das, S.K. Raut and Das B.K. (2007): Assessment of physico-chemical status of a closed Beel of Kalyani Industrial Area of West Bengal. NSL: Pp.404 - 406.

Warhate S.R. and Gahokar A.R. (2012): Application of Water quality index for assessment of lakes in Wani region, processing Innervate 2012 Jankidevi Bajaj College Wardha(M.S.). Pp. 58-60. 